\title{
VILA-MATAS, Enrique Dublinesca
}

Barcelona: Seix Barral, 20ı, 65 p

Wilson Alves-Bezerra

Professor do Departamento de Letras da UFSCar, tradutor e autor de Reverberações da Fronteira em Horacio Quiroga (Humanitas/FAPESP).

Uma versão inicial deste texto foi publicada no suplemento Cultura, do jornal Zero Hora, em 22 de janeiro de 2011. 
O ESCRITOR CATALÃo EnRIQUe Vila-MATAs tem uma trajetória singular. Desde a juventude transita entre Barcelona e Paris, onde viveu por muitos anos, tendo sido inclusive inquilino de Marguerite Duras. A França é referência frequente em seus livros: Marcel Duchamp é alçado à condição de figura-chave na revelação do complô literário que dá corpo à trama de Historia abreviada de la literatura portátil (I985); o escritor francês Julien Gracq é central nos dois últimos livros do escritor: Perder teorías (2010) e Dublinesca (2010). No primeiro, Gracq tem sua obra utilizada como ponto de partida para uma "teoria geral do romance"; o segundo e principal livro funciona como a realização da teoria imaginária do primeiro. Ambos funcionam, em diferente medida, como um acerto de contas com o grupo da revista francesa Tel Quel.

Foi justamente essa conexão francesa de Vila-Matas que lhe rendeu, em dezembro passado, o prêmio Jean Carrière, que laureia “obras em língua francesa ou traduzidas que celebrem a herança literária e cultural do Sul e do Mediterrâneo". A versão francesa de Dublinesca foi a vencedora. Ironicamente, tratase de um livro em que o protagonista é mordaz com a França e a Espanha, e volta-se justamente para a Irlanda de James Joyce e de Samuel Beckett. De toda forma, a honraria, ao lado do também recente prêmio espanhol Leteo, pelo conjunto da obra, e a tradução dos livros do autor a mais de trinta idiomas indicam que Vila-Matas vai sendo elevado à condição de unanimidade. Diferentemente do que pode sugerir a imagem de escritor consagrado, ele dá mostras de estar longe do ponto de chegada. Dublinesca traz muito de uma inquietação que se pode atribuir a quem não automatizou o exercício da escrita nem o da leitura. Juntamente com o pequeno ensaio Perder teorías, os novos livros de Vila-Matas colocam em discussão a morte da Galáxia de Gutenberg, a instância do autor e do editor no mundo contemporâneo.

Perder teorías é o relato do escritor famoso subitamente esquecido num hotel em Lyon pela organização de um evento, e que se compraz da sua invisibilidade 
rascunhando a já citada teoria geral do romance. Ademais do resgate do mundo solitário da experiência literária em tempos de sociedade do espetáculo, o debate sobre a discussão francesa sobre o lugar do romance e o da teoria é saborosamente renovado, através de sua exageração grotesca: “Era a mediados de los años setenta y la teoría triunfaba en todos los medios intelectuales de la ciudad. Había incluso empezado a considerarse una grosería pasarse de la teoría a la práctica y escribir, por ejemplo, un cuento o una novela. En aquellos días estaba muy bien visto no ir más allá de la teoría. ¿Para qué repetir lo que ya se había narrado tantas veces?" (Perder teorías, I5).

Em Dublinesca, acrescenta-se uma terceira instância, além da do teórico e do escritor, a do editor. Quem representa este papel no romance é seu protagonista, Samuel Riba, um editor catalão de sessenta anos, cujo sonho juvenil era editar livros na França, que seriam objetos de desejo dos jovens esquerdistas frequentadores da livraria Maspero, que os roubariam fascinados, sob o olhar complacente dos vendedores. O tempo passou e Riba, apesar de ter se tornado um editor mais ou menos respeitado, arrasta as correntes do fracasso através da sua aposentadoria precoce. Mesmo se considerando pertencente "a la cada vez ya más rara estirpe de los editores cultos, literarios” (Dublinesca, II), passa os dias na frente de seu computador, à deriva do que lhe ofereça o google, onde pesquisa obsessivamente o próprio nome. E pensa sobre o fato de nunca ter descoberto e editado um autor genial.

$\mathrm{O}$ editor fracassado frequenta protocolarmente às quartas-feiras a casa dos pais para contar-lhes da última viagem, interpretando diante deles o papel do homem de negócios e letras bem sucedido e ocupado. E se pergunta se ultimamente não tem viajado apenas para contar aos pais coisas dignas de nota. Diante de tantos senões em sua trajetória, decide dar uma virada em sua vida, e para tanto opta por, paradoxalmente, fazer outra viagem. O destino é Dublin, em i6 de junho, o Bloomsday e, coincidentemente, também a data do aniversário do pai. 
Às portas da velhice, abstêmio, aposentado, a empreitada dublinense lhe servirá para mostrar se de fato não havia o grande autor buscado por toda a vida, se a era da literatura impressa de fato teria chegado ao fim. O que torna Samuel Riba interessante ao leitor não é meramente sua dimensão bobalhona de fracassado bonachão, mas a perspectiva literária através da qual organiza seus solilóquios. Assim, as sucessivas associações de autores, cenas de cinema, fragmentos literários permitem dar consistência aos pensamentos do editor, chamado de autista pela esposa recém convertida ao budismo. E as angústias de Riba são ponteadas por lembranças de passagens de James Joyce, Samuel Beckett, Julien Gracq, Juan Carlos Onetti, Jorge Luis Borges, Julio Cortázar, canções de Tom Waits, Bob Dylan, um quadro de Hopper, enfim, uma tessitura de citações artísticas que conforma seus dias e torna transmissível ao leitor sua experiência.

É preciso esclarecer, entretanto, que as tais citações não necessariamente são verdadeiras; Vila-Matas acostumou-se a embaralhar as fontes, e a colocar frases próprias em bocas alheias. Liz Themerson - professora da George Washington University, tradutora de Bolaño e Ribeyro ao inglês, e que é citada no livro Perder teorías - desmente a suposta citação dela já no prefácio à obra, e ainda diz que na edição francesa (Perdre des théories, Trad. Christian Bourgois, 20ıо), a mesma frase é atribuída ao fictício escritor Vilém Vok, mas que na verdade trata-se de uma passagem de Samuel Bellow... Estamos diante da versão contemporânea do procedimento joyciano das montagens de palavras em seu Finnegans Wake, agora trazido para o campo das citações, com o objetivo de entreter os eruditos vida afora. Nas palavras do narrador de Perder teorías, “mi literatura ha exasperado y llevado hasta el límite el uso de las citas literarias distorsionadas, [...] mi falsa erudición ha funcionado casi como una sintaxis o modo de darle forma a los textos" (2010, 32).

Outro modo de entender este embaralhamento dos nomes próprios é aquele trazido pelo narrador de Perder teorías, via uma citação de Philippe Sollers, a 
qual pode ser entendida como uma sorte de aniquilamento da individualidade criadora: "Hay que hacer desaparecer al señor que se pasea por todas partes con su nombre propio, que es propietario de su producto, que lo convierte en una mercancía estética, literaria, musical o pictórica" (Sollers apud Vila-Matas, Perder teorías, I5-6). A realização do romance de Vila-Matas é a própria abolição deste nome próprio, seja pela tessitura de citações, seja pelo centro vazio que conforma a busca vã de Samuel Riba.

A indistinção entre vida e literatura, que levou o protagonista de Dublinesca a conceber-se como personagem de um autor desconhecido, é uma marca que faz parte do projeto literário de Vila-Matas, e se apresenta em duas dimensões: quando ficcionaliza o métier dos escritores e lhes atribui uma dimensão insólita; e quando relê a tradição literária, e a desestabiliza. O precursor destes procedimentos é o Borges dos contos Pierre Menard, autor del Quijote e Tlön Uqbar, Orbis Tertius: o mesmo texto em boca alheia renova o dito, para dizer o mínimo.

Certamente, Vila-Matas não é o primeiro hispânico a enveredar por estas paragens. Outros contemporâneos seus poderiam ser lembrados. O argentino Ricardo Piglia, em Ciudad Ausente (I992), compôs um relato em que realizava algumas metáforas da tradição literária ocidental, e assim o anti-romance de Macedonio Fernández, Museu de la Novela de la Eterna, era transformado em um museu de fato, aberto à visitação, enquanto que o Finnegans Wake de Joyce tornava-se Livro Sagrado num tempo futuro. O leitor que frequenta o livro de Piglia se embrenha na tempestade de citações ordenada sob a forma do romance policial ambientado em tempos apocalípticos. Já o personagem de Vila-Matas sabe que fazer homenagens a sério em nossos dias é descabido, pois até "lo apocalíptico sólo puede ser ya tratado de forma paródica" (Dublinesca, I20). São justamente o humor e a impostura que permitem ao romance de Vila-Matas livrar-se da pretensão desmedida e da eruditice.

Mesmo o cáustico chileno Roberto Bolaño, que também operou na conexão vida e literatura, mostra-se distante deste romance de Vila-Matas. Na primeira 
parte de seu póstumo 2666 conta-se a história de alguns jovens intelectuais de vinte e poucos anos que se reunem em busca de um autor obscuro, Archimboldi, que vai sendo monumentalizado ao longo do livro. Em Vila-Matas, trata-se de um homem de sessenta que organiza uma viagem a Dublin com alguns amigos em busca de um grande ator que já se sabe de antemão inexistente ou morto. Sutil diferença.

Se há algum monumento erigido em Dublinesca é o da impossibilidade do grande escritor, ao ponto de a viagem iniciática de Samuel Riba a Dublin ser para um funeral paródico e uma volta ao alcoolismo. Com o humor que lhe é peculiar, o escritor traz em sua escrita não apenas a morte textual do autor (cf. Barthes, I968) mas também, num panorama muito sombrio, a derrocada real do leitor e o fracasso do editor que ainda crê no gênio. 